\title{
Ferrous Ion Effect on Pigeon Liver Pyruvate Kinase
}

Pigeon liver pyruvate kinase is a regulatory enzyme ${ }^{1}$. It shows cooperative interaction with phosphoenolpyruvate, allosteric inhibition by ATP and allosteric activation by fructose-1,6-biphosphate. The enzyme, which has an obligatory requirement of divalent cations, is activated by $\mathrm{Mg}^{2+}$ and $\mathrm{Mn}^{2+2}$. The present experiments indicate that ferrous ions stimulate the $\mathrm{Mg}^{2+}$ activated pigeon liver pyruvate kinase and that this effect is dependent upon the phosphoenolpyruvate concentration.

Materials and methods. All reagents were of analytical grade. Fed male pigeons were used as liver donors. The livers were homogenized with 2 parts of $0.25 M$ sucrose and centrifuged for $10 \mathrm{~min}$ at $10,000 \times \mathrm{g}$. The supernatant was centrifuged again for $1 \mathrm{~h}$ at $105,000 \times \mathrm{g}$. Before being used for enzyme assay, the supernatant at $105,000 \times g$ was incubated for $2 \mathrm{~h}$ at $25^{\circ} \mathrm{C}^{1}$.

Pyruvate kinase (EC 2.7.1.40) was assayed by the method of Bücher and PFLEIDERER ${ }^{3}$. The volume of the reaction mixture was $1.0 \mathrm{ml}$ and the reagents were: Tris- $\mathrm{HCl}$ pH $7.050 \mathrm{~m} M$; $\mathrm{KCl} 0.1 M$; NADH $0.15 \mathrm{~m} M$; ADP $1.0 \mathrm{~m} M$; lactate dehydrogenase (Biochemia s.r.l., Milano, Italia) $0.5 \mathrm{U}$. The enzyme activity was expressed as $\mu$ Moles of $\mathrm{NADH}$ oxidized $\times \mathrm{min}^{-1} \times \mathrm{g}^{-1}$ of tissue and calculated from initial velocity. The phosphoenolpyruvate, the $\mathrm{FeCl}_{2}$ and the $\mathrm{MgCl}_{2}$ concentrations were as indicated in the legend of the Figure.
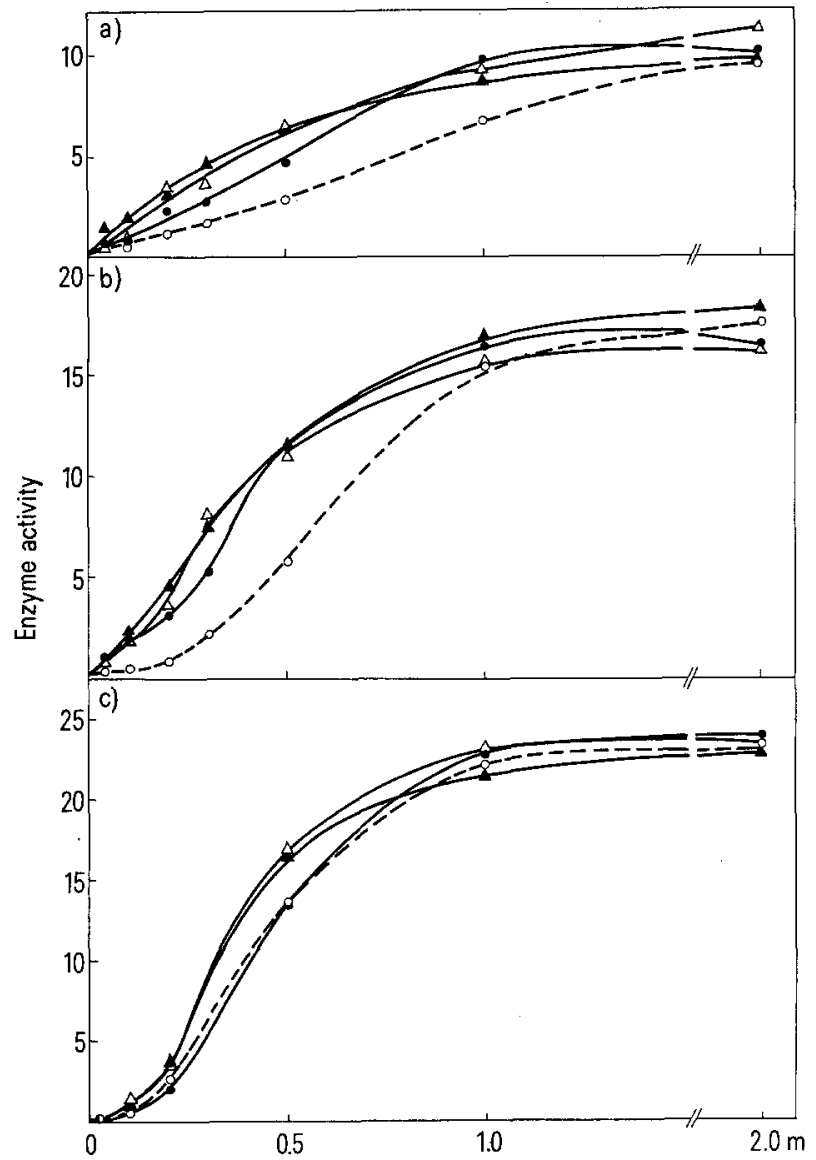

Effect of $\mathrm{Fe}^{2+}$ on pigeon liver pyruvate kinase. The assay system was as described in the test, with $1.0 \mathrm{mM} \mathrm{MgCl}$ in a), $5.0 \mathrm{mM} \mathrm{MgCl}$ in b) and $10.0 \mathrm{mM} \mathrm{MgCl}$ in c). $\bigcirc$ (broken line), no $\mathrm{FeCl}_{2} ; 0,0.025 \mathrm{mM}$ $\mathrm{FeCl}_{2} ; \triangle, 0.05 \mathrm{mM} \mathrm{FeCl} ; \Delta, 0.1 \mathrm{mM} \mathrm{FeCl}{ }_{2}$.
Results and discussion. Ferrous ions act on the pigeon liver pyruvate kinase, reducing the sigmoidicity of phosphoenolpyruvate (PEP) saturation curve. The $\mathrm{Fe}^{2-1}$ action on the enzyme results in a strong activating effect at low PEP concentrations, an effect that is progressively reduced by increments of $\mathrm{PEP}$ concentrations. The $\mathrm{Fe}^{2+}$ effect is present in the $3 \mathrm{Mg}^{2+}$ concentrations tested (Figure a, b, and c). As consequence of the $\mathrm{Mg}^{2}+$ influence on the PEP cooperative effect, the $\mathrm{Fe}^{2+}$ activating effect on the pyruvate kinase is quantitatively dependent upon the magnesium ion concentrations. The maximal activating effect is observed when the enzyme is assayed in presence of $5 \mathrm{mM} \mathrm{Mg}^{2+}$ with a stimulation of the pyruvate kinase activity equal to $400 \%$ of the control value (at $0.2 \mathrm{~m} M \mathrm{PEP}$ ).

The allosteric nature of the liver pyruvate kinase suggests that the ferrous ion can be positive effectors of the enzyme when it assumes conformations characterized by low catalytic activity; when the enzyme is shifted towards more active conformations, the $\mathrm{Fe}^{2+}$ activatory effect is reduced or even lost.

$\mathrm{Ca}^{2+}$ has an activatory effect on the pigeon liver pyruvate kinase ${ }^{2}$ similar to the $\mathrm{Fe}^{2+}$ one. These divalent cations are able to stimulate pyruvate kinase enzymes that have sigmoidal PEP saturation curve. The muscle pyruvate kinase which has an hyperbolic curve of activity in function of PEP concentration, is inhibited by $\mathrm{Fe}^{2+4}$ and $\mathrm{Ca}^{2+2,5}$.

Ferrous ion may play a role in the carbohydrate metabolism. It has been proposed as a physiological activator of the rat liver phosphoenolpyruvate carboxykinase $^{6}$, a metallo enzyme that, like the pyruvate kinase, can be activated by $\mathrm{Mg}^{2+}$ and $\mathrm{Mn}^{2+7}$. Ferrous ions can be considered as effectors for the regulation of the pigeon liver pyruvate kinase. Changes of $\mathrm{Fe}^{2+}$ concentrations in the hepatocyte will determine changes in the activity of the enzyme, and a proper constant concentration of $\mathrm{Fe}^{2+}$ can maintain a high enzyme activity in metabolic conditions in which a low steady concentration of PEP is present $^{8}$

Riassunto. L'azione dello ione ferroso è stata studiata sulla piruvato cinasi del fegato attivata da $\mathrm{Mg}^{2+} \cdot \mathrm{Fe}^{2+}$ stimola la attività catalitica dell'enzima dosato in presenza di basse concentrazioni di fosfoenolpiruvato, a concentrazioni saturanti di questo substrato l'effetto di attivazione è minimo o assente.

\section{F. Gabrielli and S. Baldi ${ }^{9}$}

Istituto di Chimica Biologica dell'Università di Pisa, Via Roma 55, I-56100 Pisa (Italy), 11 June 1974.

1 F. Gabrielli and S. Baldi, Eur. J. Biochem, 31, 209 (1972) ${ }^{2}$ F. Gabrielli and S. Baldi, Experientia 29, 1342 (1973). 3 T. Bücher and G. Pfleiderer, Meth. Enzym. 1, 435 (1955). 4 F. GABRIELLI and S. BALDI, unpublished data.

5 A. S. Mildvan and M. Cohn, J. biol. Chem. 240, 238 (1965).

${ }^{6}$ R. E. Snoke, J. B. Johnston and H. A. Lardy, Eur. J. Biochem. 24, 342 (1971).

7 D. D. Holten and R. C. Nordlie, Biochemistry 4, 723 (1965). 8 This work was supported by a grant from the Consiglio Nazionale delle Ricerche, Roma, Italia. Silvia Baldi was a fellow of the Italian C. N. R.

9 Acknowledgment. The authors thank Mr. P. Bertelli for technical assistance. 